TEME, г. XLIV, бр. 3, јул - септембар 2020, стр. 1101-1116

Прегледни рад https://doi.org/10.22190/TEME190220068L

Примљено: 20. 02. 2019.

UDK 368:502.1

Ревидирана верзија: 19. 8. 2019.

Одобрено за штампу: 1. 10. 2020.

\title{
COMPARATIVE FRAMEWORK FOR THE ENVIRONMENTAL LIABILITY INSURANCE
}

\author{
Ozren Uzelac' ${ }^{1}$, Mario Lukinović ${ }^{*}$ \\ ${ }^{1}$ University of Novi Sad, Faculty of Economics in Subotica, Subotica, Serbia \\ ${ }^{2}$ Faculty of Law of the Union University, Belgrade, Serbia \\ *mario.lukinovic@pravnifakultet.rs
}

\begin{abstract}
Growth of population and economic activity contribute to the increasing number of ecological incidents, which derive from different sources causing multiple types of pollution. Legal framework for selling this type of insurance was created by the introduction of the mandatory pollution liability insurance and the adoption of the insurance terms and conditions. In this paper, the author deals with several legal aspects of environmental liability insurance and those types of losses. Particular focus was on the notion of the ecological loss and object of coverage, insured event and period of insurance, sum insured and insurer duty. Authors conclude that the separation of the insurance (and terms and conditions) against environmental liability into a stand-alone product could be the next step in developing insurance conditions of the domestic insurance companies.
\end{abstract}

Key words: $\quad$ Pollution, Damage, Tort, Retroactive Cover, Serial Loss.

\section{УПОРЕДНИ ОКВИР ЗА ОСИГУРАҢЕ ОД ОДГОВОРНОСТИ ЗА ЕКОЛОШКУ ШТЕТУ}

\section{Апстракт}

Пораст становништва и привредних активности човека доприноси све већем броју еколошких инцидената, који се разликују по изворима опасности и према врстама загађења. После увођења обавезног осигурања од одговорности за загађење и доношења услова осигурања, створен је правни оквир за спровођење те врсте осигурања. У овом раду аутори се баве појединим правним аспектима осигурања од одговорности за загађење животне средине и тиме насталих штета. Посебно су анализиране дефиниција еколошке штете и предмет покрића, осигурани случај и период осигурања, сума осигурања и обавеза осигуравача. Аутори закључују да би издвајање осигурања (и услова осигурања) од еколошке одговорности у самосталан производ осигурања могао да буде следећи корак у развоју услова осигурања домаћих друштава за осигурање.

Кључне речи: загађење, штета, вануговорна одговорност, ретроактивно покриће, серијска штета. 


\section{INTRODUCTION}

Growth of population and economic activity contribute to the increasing number of ecological incidents, which derive from different sources causing multiple types of pollution. Pollution and the degradation of the environment are done directly or indirectly by people, by disturbing the integrity of the ecosystem, which leads to the degradation of nature and causes harm to human health (Belencan, Marković, 2015, 251). Our country generates about 100,000 tons of dangerous waste such as motor oil, electric and electronic waste, scrapped cars and car tires, batteries and car batteries annually, $40 \%$ of which is not being processed into harmless materials, and a big amount of dangerous oils end up in rivers (Jokić, Stamenković, 2017, 8 ). When analyzing the reasons that influence higher or lesser occurrence of ecological incidents, the high number of lawyers per capita in a certain country is a sure indicator of higher expenses of litigations in the field of liability insurance in comparison to countries that have a lesser number of lawyers per capita (International Comparisons of Litigation Costs, June 2013, 2). Harmonized business of insurance companies with the taken risks is of great importance for every economic system (Janković, 2018, 1). The environmental protection insurance market has only begun to develop during the last few years (Faure, Jing, 2013). The fact that the consequences of pollution might appear later, within the period of a few months or many years represent a special problem, and most of the insurances are concluded for a period of one year (Kreuzer, 2001).

The issue of costs of damage prevention is a noticeable difference in insurance concepts (Vujović, 2009, 472). In Sweden, the mandatory insurance system has been in action since 1989 in order to compensate the damage when the polluters cannot be identified. In order to be insured from the avoidance of damages towards the environment, as well as from the alleviation of consequences, in France, quarry and waste storage facilities operators are required to provide financial guarantees for the cost of mitigating the damage incurred. In Belgium, insurance is mandatory for waste import and export, as well as for the work of oil storage facilities. Spain has normalized mandatory liability insurance for the accountability of pollution for companies that work with dangerous waste in chemical industry and storage facilities operators for the disposal of waste and tires (Stavins, 2002, 20.).

At the European Union level (hereinafter: EU), the Environmental Liability Directive regarding the prevention and repair of ecological damage $^{1}$ obligated member-states of the EU to oblige facility operators to

${ }^{1}$ Directive 2004/35/CE of the European Parliament and of the Council of 21 April 2004 on environmental liability, with regard to the prevention and remedying of environmental damage, Official Journal of the European Law, L 143, 30.4.2004, p. 56-75. 
conclude suitable insurance or to provide some other sort of financial security for covering the consequences of ecological damage (Directive 2004/35/CE, preamble no. 27 and Art. 14). Even though the Directive stipulates the liability of polluters for damaging consequences of their actions and strengthens legal legitimacy and access to information and the decision-making process of associations for environmental protection, its application is not sufficient for reaching sustainable development (Radojević, 2005). Regarding mandatory insurance, EU member-states are free to decide on the method of insurance of individuals performing dangerous actions, that is, whether they will use insurance, bank guarantee or some other alternative security mechanisms. Only a small number of EU member-states has opted for voluntary financial insurance mechanisms, while eight states have accepted mandatory financial insurance mechanisms (Labudović, Stanković, 2012).

The same year the previously mentioned EU Directive was passed, the Republic of Serbia passed the Law on Environmental Protection (hereinafter: LEP) and thus introduced mandatory liability insurance for polluters whose facilities or activities represent a high level of danger for human health and environment, in case of damage being done to third parties due to an accident (the Law on Environmental Protection, 2004, Art. 106). However, the LEP did not regulate at all the details regarding the content of this type of insurance, which is typical for all kinds of business liability insurance, which has been, within our legal theory, pointed out as a flaw in legal regulation of mandatory liability insurances (Slavnić, 2011, 186-189). This specifically refers to the issue regarding the type of damage for which the facility operator must be insured against ecological liability towards third parties, the amount of insurance, etc.

Apart from mandatory liability insurance for polluters, in Serbia, the legal obligation for other subjects to have liability insurance for damages that might be caused by harmful substances has been introduced in the field of general liability. In this paper, we will dedicate special attention to certain aspects of liability insurance for pollution of the environment and thus incurred damage. Before we start with the main presentation, we shall note that, on the domestic market, liability insurance for ecological damage is being concluded within the scope of general liability insurance. This means that the insured must first conclude a general liability insurance in order to expand the coverage to ecological liability as well. Moreover, integrated liability coverage of the activity and ecological liability in favor of the separate (special) conditions and insurance policies were abandoned in the developed insurance markets. 


\section{DEFINITION OF ECOLOGICAL DAMAGE AND THE SUBJECT OF COVERAGE}

In the sense of the insurance conditions, ecological damage implies environmental pollution including deterioration of air, land and/or water quality. ${ }^{2}$ The terms pollution of the "environment" or "human environment" are synonyms that should linguistically exclude the use of one of them. Even though both terms are crystal clear, they do not in fact precisely point out what is included by suitable coverage, that is, by the obligation of the insurer. The phenomenon of ecological risk has been in use in Europe in a way as it is used in the United States (Suter II, 2007, 3).

The other way of defining ecological damage provides, as the authors believe, a more precise description which implies that "the pollution of lands and waters imply alternation of biological, chemical or physical natural features of the lands or waters due to the release of harmful substances that might cause such changes". ${ }^{3}$ We duly note the following different terms with contents oriented towards coverage of the same type of damage within the insurance conditions are being used: damage caused by pollution, that is, ecological damage.

These types of insurances are subjected to the conditions of liability insurance that state that the subject of insurance is the civil-legal liability of the insurers for damages caused by death, bodily or health injuries, as well as destruction or damage of third party's belongings, if the said damage occurred from acting on or owning belongings, within the legal framework or within the source of danger that is mentioned in the contract, that is, in the insurance conditions. ${ }^{4}$ The insurance covers the non-contractual civil liability of the insured regarding the caused ecological damage, and the coverage of the contracted liability is determined separately.

However, the issues of liability insurance towards third parties, as well as ecological liability insurance, represent an institution of solidary responsibility which states that, in cases when the damage is caused by more individuals together, all individuals are equally responsible. As stated within the foreign theory (Faure, 2009, 266), this represents the possibility that when the damage is caused by an individual that is not insured, due to solidary liability for the ecological damage, the compensation claim might be filed against the insurer. In this sense, the insurer might be obliged to compensate the damage that was not caused by the insured, but that the said insurer, according to general rules of

${ }^{2}$ Conditions for liability insurance in the field of damage caused to third parties, Wiener Städtische insurance, Art. 22.

${ }^{3}$ Conditions for liability insurance, Energoprojekt Garant ADO, Art. 6, Par. 1.

${ }^{4}$ Ibidem, Art. 3, Par. 1; Conditions for General Liability Insurance, Generali Insurance Serbia, Art. 2. 
civil-legal liability, is obliged to compensate. We believe that the stated type of non-contractual obligation is covered by the insurance conditions of the domestic market, since the source of danger includes "the insured activities, belongings (mobile and immobile), a legal relation or specific feature from which responsibility might emerge (Italic added by the author)

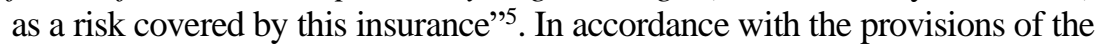
Law on Obligations Article 170 and 176, joint liability is stipulated in such a way that the injured party might file a claim with the insurer, but also with the insured (a company that is liable for damage under the principle of strict liability), as well as with a natural person that is employed with the insured or has previously used any of its belongings whose hidden defects or features caused the damage, of which the given person was not warned.

Concrete activities covered regarding the occurrence of ecological damage liability are not stated within the insurance conditions of the domestic insurance companies. General ecological damage liability conditions of the German insurance company Allianz Deutschland precisely state the activities during which this kind of danger is covered. Thus, the insurer provides coverage regarding the ecological damage liability: (a) during fulfillment of the obligation of the provision of service, construction projects, oil, gas or fuel storage, (b) production or deliverance of products $^{6}$ and (c) planning, production, shipment, installation, deinstallation, maintenance or servicing of the equipment. ${ }^{7}$

However, by having insurance for ecological liability, even though it is not explicitly included in the insurance conditions among domestic insurance companies, it might be concluded that the damage caused to protected plant and animal species and natural habitats is not covered, even though the polluter, ex lege, is obliged to also compensate this type of ecological damage. Coverage of this type of damage, within the sense of the LEP, reflects in the coverage of the financial value of the said flora and fauna, the treatment of the injured or ill specimen of wild flora and fauna, including active protection measure such as reintroduction and repopulation.

\footnotetext{
${ }^{5}$ Conditions for liability insurance in the field of damage caused to third parties, Wiener Städtische insurance, Art. 2, Par. 1, It. 12; Conditions for General Liability Insurance, Generali Insurance Serbia, Art. 1, Par. 1, It. 9; Conditions for liability insurance, Energoprojekt Garant ADO, Art. 2, Par. 1, It. 11.

${ }^{6}$ At this point, we shall point out the fact that domestic insurers exclude the obligation for ecological damage on the products of insures with a defect (Conditions for liability insurance in the field of damage caused to third parties, Wiener Städtische insurance, Art. 6, Par. 2, It. 3; Conditions for General Liability Insurance, Generali Insurance Serbia, Art. 5, Par. 2, It. 3).

${ }^{7}$ Allgemeine Versicherungsbedingungen für die Öko-Haftungsversicherung für Betriebe, Berufe, Immobilienbesitzer und Bauherren Baustein I (hereinafter: AVÖ), Allianz Deutschland AG, H 6162/03, Art. 2.
} 
The conditions of ecological damage liability insurance practically do not mention the coverage of the said property damage, nor the financial obligations - expenses for which the state body might oblige the insurer in the name of the compensation for the mentioned property damages or the expenses of conducting sanitary measures, remediation of natural habitat or other similar obligations, while, according to insurance conditions of the German insurance companies ${ }^{8}$ and American insurance companies ${ }^{9}$, this type of damage is explicitly covered by insurance. It is practically about the property damage of a natural good within the public property of the Republic of Serbia, the autonomous province or the local self-government unit that is not covered by the conditions of the ecological damage liability insurance for the third party.

According to the Conditions of ecological liability insurance of the German insurance company Allianz Deutschland $A G$, the insurer compensates the damage of protected species, natural habitats or waters, as follows: (1) the expenses of primary rehabilitation, that is, sanitary measures that re-establish natural resources or disturbed functions to their fullest to approximate the extent in comparison to the state before the insurance case; (2) the expenses of additional rehabilitation, that is, the renewal of natural resources or functions if the primary rehabilitation does not provide the complete establishment of damaged natural resources or functions and (3) rehabilitation expenses in order to compensate for the temporary loss of natural resources or functions after the insured case, up to the moment when the primary rehabilitation produces an entirely remedial effect. Temporary loss is the loss of ecological function of the damaged natural resources or functions up to the moment of full capacity of primary and additional remediation measures.

Compensation of the expenses of rehabilitation of the degraded lands includes the expenses of the measures necessary for the removal, control, absorption or reduction of the pollutants in such a way that the polluted lands, in accordance with the course of approved future use, does not represent a risk for human health. Given that the previously mentioned insurer also provides coverage for the dead protected species, the damage of natural habitats and waters, the previously mentioned restriction that recovery and other measures shall be taken only within the measure that does not represent a higher danger to human health is not logical, but the coverage should also include the expenses of the previously mentioned measures that would ensure that the polluted lands and waters do not represent a higher danger to the health of plant and animal world.

\footnotetext{
${ }^{8}$ Ibidem, Art. 1.1 .

${ }^{9}$ CHUBB Contractors Pollution Liability and Errors \& Omissions Insurance Policy, PF-29498 (04/10), V - Definitions, p. U.
} 
If we deliberate on the practice in other legal systems, we will find that, when speaking of ecological damage, one of the fundamental problems is the difficulty of determining the causal link in relation to the wide-spread and latent types of damage (Faure, 2007). Here, we have the discrepancy between theory and court practice. Johnson believes that all ambiguities regarding the insurance conditions in the contract should be resolved in favor of the insurer (Johnson, 2004). On the other hand, the California Supreme Court has decided on the factors that are used in courts for determining the reasonable expectations of the insured: 1) the type of purchased insurance 2) whether everything included in the report is linguistically precisely determined; and 3) the basis of the responsibility of the insured, including whether this responsibility emerged from usual business operations of the insured (Noel, 2007, 494).

\section{INSURANCE EVENT AND THE PERIOD OF INSURANCE}

The insured case is in action only if the endangerment of the environment is caused by individual, sudden, unexpected event that deviates from the regular, undisturbed event at work. ${ }^{10}$ This means that the insurance excludes intended and fraudulent causing of the insured case. The insurer is especially exempted from the obligation if the ecological damage was caused as a result of a mistake or a failure of the insured to act in accordance with the laws, other regulations (especially the regulations regarding the protection of the environment - author's remark) and other state body's acts, the lack of maintenance, insufficient maintenance or non-fulfilment of urgent repairs and other urgent works on the facility, objects and the equipment (for example, appliances for cleaning wastewater and other waste products).

The insured case represents the first ascertainment of the ecological damage that could be examined, and based on which the damage compensation obligations emerge or might emerge. Given that domestic insurance companies exclude their ecological damage obligation occurring on the products of the insured, they do not exclude in their conditions the said obligation for the cases when the defect of a product might have been determined in the time of it being distributed on the market in accordance with the state of science and technology in the given moments, as is the case with German insurance companies. ${ }^{11}$

When speaking of the period of the insurance coverage, insurance covers the ecological damage that is determined during the period of the

${ }^{10}$ Conditions for liability insurance in the field of damage caused to third parties, Wiener Städtische insurance, 15.1.2007, Art. 22, Par. 3; Conditions for General Liability Insurance, Generali Insurance Serbia, K-OD-814, Ecological damages, Art. 1; AVÖ, Art. 3.1.

${ }^{11}$ AVÖ, Art. 3.2. 
validity of the insurance or two years afterwards to the latest (respiro or Sunset Clause in Anglo-Saxon legal systems -author's note), whilst the damaging event must occur within the period of insurance. It might be seen that the insured case occurred when the insured, authorized body or the third injured party determines or becomes aware of the occurrence of the ecological damage. If the insured case is determined during the period of the insurance due to a cause that originated before the time of the conclusion of the insurance contract, the ecological damage is insured only if the following two cumulative conditions are met: (1) if the cause or the event happened at least two years before the conclusion of the insurance contract and (2) if the insurance contractor, that is, the insured, was not aware and could not be aware of the cause, event or the ecological damage until the conclusion of the contract. ${ }^{12}$ In this case, the conditions of the general liability insurance of domestic insurance companies provide retroactive coverage to the insured, even though in the time of the conclusion of the insurance contract it might have been known whether it was needed (for example, a business entity or facility that is only set in action at the moment or immediately before the conclusion of the insurance contract definitely does not need an retroactive coverage). However, retroactive insurance coverage for ecological liability is a desirable instrument for the seller of a company or a facility that wishes to achieve a "clean exit" from the potential obligations to such risks (Davies, Green, 2015), while on the other hand, the possibility that the insured might contract retroactive coverage for a period longer than two years prior to concluding the insurance contract. Within the Anglo-Saxon practice, retroactive coverage is left to the freedom of an agreement, that is, it is not contracted in advance by insurance conditions, which means that the insured must arrange this separately. The insured does so in the insurance bid form printed by the insurer with the content determined in advance in which, within the suitable column, the insured states the date in the past from which the said insured wishes to have retroactive coverage. The insured is free to determine the length of retrospective coverage, under the condition that the insurer accepts to obligate for a longer period of time within the business activity of the insured in the past. Whether the insurer accepts the longer retroactive period depends, in the Anglo-Saxon practice, on the case circumstance, the nature of the business of the insured, the history of damage, the trust of the insurer in the information acquired from the insured, etc. Within the domestic insurance market, there are examples of liability insurance conditions that do not include retroactive coverage ${ }^{13}$, even though it can be arranged, as stipulated in Art. 898, Par. 3 of the Law on Obligations.

12 Conditions for liability insurance in the field of damage caused to third parties, Wiener Städtische insurance, 15.1.2007, Art. 22, Par. 6; Conditions for General Liability Insurance, Generali Insurance Serbia, К-ОД-814, Ecological damage, p 4.

${ }^{13}$ Conditions for liability insurance, Energoprojekt Garant $A D O$. 
When determining the premium, it is necessary that there are: chances for an accident; possibility that, if an accident happens, a lawsuit would be filed, and the statement that the insured/reinsured would have to pay. If the elements themselves are uncertain, it would be difficult for the insurer to determine the "safe" premium, and thus, it is difficult for the insurer to offer the insurance for the premium that the customers are ready to pay (Kunreuther, 1987).

\section{INSURANCE OBLIGATIONS REGARDING PREVENTION MEASURES EVEN AFTER THE OCCURRENCE OF THE INSURED CASE}

Besides the obligation of the insured to report all the facts that are important for the risk assessment when concluding the contract, the insured is also obliged to pay the insurance premium and other obligations. In this section of the paper, we will analyze special obligations of the insured in terms of taking prevention measures, as well as obligations after the occurrence of the harmful event included in the insurance.

The general obligation of the insured is to act in accordance with the laws, other regulations and acts passed by state bodies.

On the other hand, the application of the principle of conscientiousness and conduct of a good businessman stipulates that in the case of taking other preventive measures, the insurer is exempted from the obligation of covering the ecological damage if the insured did not conduct measures for preventing the occurrence of the increase of danger, as demanded by the insurer. Besides, the insured must ensure regular professional maintenance, changing and repairing the machines / appliances, objects and other equipment that could easily endanger / pollute the environment. ${ }^{14}$ Irreversible actions of the insured are existent when urgent repairs and other works regarding the maintenance that must be done at once, without any postponement, are not conducted, as well as when the insured is not compliant with other measures stipulated in the regulations on the environment protection. According to insurance conditions of the American insurance company Chubb, in the case of the occurrence of pollution, the insured is obliged to attempt everything in order to reduce the damage or the cost of the urgent response, as well as to act in accordance with the applicable regulations. ${ }^{15}$

\footnotetext{
${ }^{14}$ General liablity insurance conditions, Generali Insurance Serbia, K-OD-814, Ecological damage, p. 5 and 6; Conditions for liability insurance, Energoprojekt Garant ADO, Art. 6, Par. 6; Conditions for liability insurance in the field of damage caused to third parties, Wiener Städtische insurance, WS.C06.1. C. 2110, 15.1.2007, Art. 22, Par. 7.

${ }^{15}$ CHUBB Contractors Pollution Liability and Errors \& Omissions Insurance Policy, PF-29498 (04/10), V - Definitions, P. VII(D).
} 
Regarding the occurrence of the insured event and the submitted application of coverage, the insured is obliged to inform the insurer within the period of three days from learning about the insured event. ${ }^{16}$ Within the German law, the Law on Prevention and Remediation of Ecological Damage from 2007 by which the provisions of the EU Regulations 2004/35/CE were implemented regarding the ecological responsibility for the prevention and remediation of the ecological damage, stipulates that the responsible individual (facility operator) is obliged to inform the responsible body about all the important aspects of the circumstance when there is an immediate danger from the occurrence of damage to the environment, or when the ecological damage has already occurred without any postponement (Gesetz über die Vermeidung und Sanierung von Umweltschäden, 2007, Arc. 4). Besides the previously mentioned obligation of information, according to the ecological liability insurance conditions of the German insurance company Allianz Deutschland, the insured is obliged to inform the insured without postponement and in detail about the following: ${ }^{17}$

- actions taken by the state authority in order to prevent or remediate the ecological damage;

- claim submitted by the third party for cost recovery in order to prevent, confine or remediate the ecological damage;

- receiving payment alert,

- litigation,

- initiation of criminal, misdemeanor or administrative proceedings.

When speaking of the defense from the damage claimed by the third party against the insured, the conditions of ecological liability insurance of the German insurance company Allianz Deutschland stipulate the obligation of the insured to, within the prescribes deadlines, file a complaint to the decision or some other administrative act regarding the obligation of paying for the consequences of the ecological damage, and that the insured shall not ask for permission from the insurer. ${ }^{18}$ Domestic insurance conditions do not prescribe such obligation of the insured, but they do anticipate the obligation

${ }^{16}$ General liablity insurance conditions, Generali Insurance Serbia, Art. 11, Par. 1; Conditions for liability insurance, Energoprojekt Garant ADO, Art. 14, Par. 1; Conditions for liability insurance in the field of damage caused to third parties, Wiener Städtische insurance, WS.C06.1. C. 2110, 15.1.2007, Art. 14, Par. 1.

${ }^{17}$ AVÖ, Art. 29.2. We note that, according to our Law on Protection of Environment (Art. $60 \mathrm{j}$ ), chemical facility operator is obliged to immediately inform about the said chemical accident the Ministry, local self-government unit and competent authorities authorized for response in emergency situations in accordance with the regulations that determine protection and rescue, iabout the following: circumstances linked to the chemical accident, dangerous chemicals present, available data regarding the assessment of the consequences of the chemical accident for people and the environment, as well as about the taken emergency measures.

${ }^{18}$ AVÖ, Art. 29.4. 
of the insurers to defend themselves from ungrounded or excessive claims for damages together with the insured. ${ }^{19}$

According to the pollution liability insurance conditions of the American insurance company Chubb, the insured is obliged to submit to the insurer, apart the filed damage claim, mistakes of the insured or the existence of the "state of pollution", the detailed information about the following: (1) the identity of the insured and the individual authorized for dealing with the damage of pollution status files; (2) the description of the insured business; (3) the location on which the mistake was made or where the state of pollution occurred; (4) the nature or the description of the mistake, damage claim or the state of pollution; and (5) the measures taken by the insured, together with the expenses of urgent response. In case the insured does not have a chance to inform the insurer in written form in a timely fashion, the insured is obliged to take all the necessary measures in order to do so in oral form.

Of course, together with the filing of the insured case, the insured is even afterwards obliged to submit copies of all files, notices, motions, lawsuits or any other documents regarding the damage claim of the third party. The insurance conditions of the American insurance company Chubb stipulate that the insured is also obliged to authorize the insurer for acquiring the records and other information, which in domestic insurance conditions corresponds to the obligation of the insured to cooperate with the insurer.

\section{AMOUNT OF INSURANCE / OBLIGATION OF THE INSURER}

The characteristic of the insurance coverage on the domestic ecological liability insurance market is that the obligation of the insurer is restricted to a certain (smaller) percent of the amount of the general liability insurance. Such ecological damage liability insurance organization might lead to insufficient coverage (sub-insecurity) in situations when the insurer needs adequate financial protection. Within the German praxis, ecological liability coverage is restricted to $50 \%$ of the contractual amount of $5,000,000$ EUR, but the greater insurance amount can also be negotiated. The obligation of the insurer regarding the expenses and ecological damage occurs above the franchise paid by the insurer, that amounts to 250 EUR. ${ }^{20}$

According to German ecological liability insurance conditions, in case of new danger, the insurance amount is increased for the amount of 500,000 EUR, with the exception of cases when the insurance policy

${ }^{19}$ General liablity insurance conditions, Generali Insurance Serbia, Art. 12, Par. 1, It. 1; Conditions for liability insurance, Energoprojekt Garant ADO, Art. 15, Par. 1, It. 1.

${ }^{20}$ AVÖ, Art. 5.1 and 9.5. 
stipulates a lower amount. ${ }^{21}$ Within the domestic insurance market, the wished insurance amounts might be negotiated for certain subjects and danger, but the total amount for all insured cases occurred within the insurance period or one damaging even (aggregate limit) is limited by the possibility that the insurer might negotiate, through the insurance conditions, a certain amount of the negotiated insurance amounts. ${ }^{22}$

The obligation of the insurer exists only in connection with the damages that occurred due to sudden and unexpected events. However, what is characteristic of the damage caused by pollution (ecological damage) is that it can be instantly exhibited, but also even after a longer period that can last for three months or for years, when the damage occurs gradually. ${ }^{23}$ As a rule, ecological damage that emerged gradually during a longer period of time is excluded from the coverage ${ }^{24}$, given that it is not the case of sudden and unexpected damage, but the insurers might decide to cover even the gradually emerging damage in cases of pollution liability. ${ }^{25}$ On the other hand, within the American legal theory and rich judicial practice, the existence of "abruptness" and "unexpectedness" of the ecological damage was interpreted in a different way, in the sense of the (non)existence of the obligation of the insurer, except that the decision of the court always depended on the manner of interpretation of factual circumstances of the given case (Fry, Saxton, 1990, 509).

The insurers should have in mind that, if the insurance conditions do not explicitly exclude gradual pollution damage, there would be a chance that the insurers shall be obliged to cover such damage due to its abruptness (neither the insured nor the injured party had the knowledge about the long-term pollution process) and unexpectedness (the damage occurred exactly during the insurance period, or the cause emerged during the insurance period, but after the expiry of the insurance policy, within the respiro deadline). In this sense, the standpoint of the Supreme court of the Federal American Republic Colorado might be accepted when the

\footnotetext{
${ }^{21}$ AVÖ, Art. 7.1.2.

${ }^{22}$ It amounts to 10 negociated insurance amounts (General liablity insurance conditions, Generali Insurance Serbia, Art. 10, ст. 5), that is, three negociated insurance amounts (Conditions for liability insurance in the field of damage caused to third parties, Wiener Städtische insurance, Art. 11, Par. 3).

${ }^{23}$ For example, continued and gradual methane leakage from the landfill into the surrounding lands and air, or oil leakage from the tanks into the surrounding lands, wells and watercourses during a longer period of time, etc.

${ }^{24}$ General liablity insurance conditions, Generali Insurance Serbia, К-ОД-814, Ecological damage, p. 1, the last sentence; Conditions for liability insurance in the field of damage caused to third parties, Wiener Städtische insurance, Art. 6, Par. 4.

${ }^{25}$ According to Art. 6, Par. 3 of the Conditions for liability insurance, Energoprojekt Garant $A D O$, destruction or damaging of belongings is covered only if previously contracted, and even when the damage occurred gradually.
} 
pollution liability insurance conditions are not contradictory to other provisions of the conditions, and the term "abrupt" in the clause regarding the exclusion of the obligation of the insurer has more than one meaning, and the clause itself is unclear. ${ }^{26}$

The older American judiciary practice interpreted the cause within the general pollution liability insurance conditions regarding the exclusion of pollution that is not the consequence of an "abrupt and accidental" event that did not contain the definition of what is considered as abrupt and accidental insured case. During one dispute, it took the stand that when the pollution was not "expected" or "intentional" by the insured, it had to be considered as abrupt and accidental even when it was caused by an intentional action of the third party. ${ }^{27}$ On the other hand, "regular" failure of the pollution control system once or twice a week cannot be considered as abrupt or accidental, and thus, in this case, the insurer is not obliged to cover the ecological damage (Fry, Saxton, 1990, 515). Thus, it can be concluded, of course, depending on the circumstance of the specific case, that the "abruptness" feature does not always refer to the instantly occurring harmful event in case the insured was not aware of it, or did not wish for the harmful event to occur (Fry, Saxton, 1990, 517). According to the standpoint of the District Court of Pennsylvania, the harmful event is abrupt when it occurs "fast and without a warning". ${ }^{28}$

Within our law, as well as in all comparative legal systems, intentionally caused pollution or ecological damage releases the insurer from the coverage obligation. On the other hand, one should have in mind that the casual link between the attitude of the insured and the damaging consequences, taking into consideration the fact the impact of will in realization of the risk, is often inexistent. For example, drunken state or any other improper behavior that did not have any direct or indirect impact on the occurrence of the harmful event is such an example (Šulejić, 1995, 1466). Thus, from all the enclosed information follows the fact that not defining the terms "abrupt" and "unexpected" within the ecological liability insurance conditions might lead to the occurrence of the insurer's obligation due to the possibility that concrete circumstances of the gradually occurring harmful event (ecological damage) might be counted as the mentioned terms. Besides, the insurers shall take care of the possibility of applying the rules that, in case when the contract was concluded in accordance with the previously printed content, or when the said contract was in any other way prepared or suggested by only one contractual party, the unclear provisions shall be interpreted in favor of the other party (Law on Obligations, 1978, Art. 100).

${ }^{26}$ Public Service Co. v. Wallis \& Cos., 986 P.2d 924 (Colo. 1999) at 931-33.

${ }^{27}$ In the concrete case, unknown individuals have opened, on the lands of the insured, the valve of asphalt bitumen tanks that leaked (Fry, Saxton,1990, 513).

${ }^{28}$ Fischer \& Porter Co. v. Liberty Mutual Insurance Co. 656 F. Supp. 132, 140 (E.D. Pa. 1986). 


\section{CONCLUSION}

The lack of ecological consciousness, caused by bad habits, lack of knowledge and ethics (Šarković, Cvejić, Bogdanov 2016, 2) leads to an increasing number of ecological incidents that differ by the sources of danger and types of pollution. For the reason of protection of third parties from the damages caused by polluters, the legal obligation of insurance for liability for causing ecological damage is introduced.

Integrated liability coverage of the activity and ecological liability in favor of the separate (special) conditions and insurance policies were abandoned on the developed insurance markets. That might be the next step in the development of the insurance conditions of the domestic insurance companies. One of the reasons for more detailed and more adjusted formulations of the ecological liability insurance conditions, in the highest possible precise regulations of insurance conditions, should also include the abandonment of the application of the Article 100 of the Law on Obligatory Relations, so that, in case when the contract was concluded in accordance with the previously printed content, or when the said contract was, in any other way, prepared and suggested by only one contractual party, the unclear provisions might be interpreted in favor of the other party. Even though, in many aspects of the general provision of general liability insurance conditions, they can be applied also to ecological liability insurance, we believe that it is necessary to regulate the conditions of ecological liability insurance in detail. This should especially be done having in mind the specificity of this type of responsibilities, as well as special rules that are applied in cases of the occurrence of environment pollutions and certain types of ecological damages.

\section{REFERENCES}

Allgemeine Versicherungsbedingungen für die Öko-Haftungsversicherung für Betriebe, Berufe, Immobilienbesitzer und Bauherren Baustein I, Allianz Deutschland AG, $\mathrm{H}$ 6162/03, 05.13.

CHUBB Contractors Pollution Liability and Errors \& Omissions Insurance Policy, PF-29498 (04/10).

Davies, P, Green, M. (2015). "Environmental insurance", available at: http://uk.practicallaw.com/3-386-3353\#, 15.10.2015.

Directive 2004/35/CE of the European Parliament and of the Council of 21 April 2004 on environmental liability with regard to the prevention and remedying of environmental damage, Official Journal of the European, L 143, 30.4.2004, p. $56-75$.

Faure, M, G. Jing, L. (2013). "Compensation for Environmental Damage in China: Theory and Practice", Environmental damage compensation, vol. 31, 2013, pp. 240-321.

Faure, M. G. "Environmental Liability" (June 10, 2009). Tort Law and Economics, Edward Elgar, ed., pp. 247-286. 
Fry, W. R, Saxton, J. P. (1990). "Interpreting the Pollution Exclusion Clause in the Comprehensive General Liability Policy - Ohio's next step", Akron Law Review, Vol. 23, Issue 3, pp. 507-525.

Gesetz über die Vermeidung und Sanierung von Umweltschäden (Umweltschadensgesetz USchadG) vom 10. Mai 2007 (BGBl. I S. 666), das zuletzt durch Artikel 4 des Gesetzes vom 4. August 2016 (BGBl. I S. 1972) geändert worden ist.

http://www.instituteforlegalreform.com/uploads/sites/1/ILR_NERA_Study_Internatio nal_Liability_Costs-update.pdf. 12.6. 2017.

International Comparisons of Litigation Costs, June 2013 Update, U.S. Chamber Institute for Legal Reform, available at:

Johnson, S. G. (2004). "Resolving Ambiguities In Insurance Policy Language: The Contra Proferentem Doctrine and Use of Extrinsic Evidence", 33 A.B.A. THE BRIEF 33.

Kreuzer, H. (2001).“ Managing Risk with Environmental Insurance“, Pollution Engineering, Vol. 33 Issue 4, p32.

Kunreuther, H. (1987). "The Failure of EIL Coverage: Gridlock in Environmental Insurance", Environment. Jan/Feb 87, Vol. 29 Issue 1, p18.

Noel C. Paul, N. C. (2007). "The Price of Emission: Will Liability Insurance Cover Damages Resulting from Global Warming?’ Loyola Consumer Law Review, Volume 19, Issue 4 The Oil \& Gas Issue, pp. 494.

Stavins, R. N. (2002). "Experience with Market-Based Environmental Policy Instruments", Kennedy School of Government, Harvard University, W. P. No. 00-004.

Suter II G. W. (2007). "Ecological Risk Assessment" CRC Press Taylor \& Francis Group, Boca Raton, Florida.

Belencan, Z. Marković, D. (2015). „Pravo na zdravu životnu sredinu, očuvanje i razvoj civilizacije“, Teme, year XXXIX, No. 1, January-March 2015, pp. 249-262.

Vujović, R. (2009), „Upravljanje rizicima i osiguranje“, Univerzitet Singidunum, Belgrade.

Law on Environmental Protection [Environment Protection Act], Official Gazette of the Republic of Serbia, no. 135 (2004), 36/2009, 36/2009 - state law, 72/2009 - state laws 43/2011 - Decision of the Constitutional Court and 14/2016, 76/2018, 95/2018 - other law.

Law on Obligations [Contracts and Tort Act], Official Gazette of the SFRY, No. 29 (1978), 39/85, 45/89 - Decision of the Constitutional Court of Yugoslavia and 57/89, Official Gazette of the FRY, No. 31/93 and Official Gazette of Serbia and Montenegro, No. 1/2003 - Constitutional Charter.

Janković, B. (2018). „Analiza revizorskih izveštaja osiguravajućih kompanija u Republici Srbiji”, TEME, year XLII, No. 4, , pp. 1277-1295.

Jokić Stamenković, D. (2017). „Srbija ne prerađuje 40 odsto opasnog otpada”, Politika, CXIV, 37225.

Labudović Stanković, J. (2012). „Osiguranje od odgovornosti za štete”, Teme, year XXXVI No. 3 pp. 1261-1278.

Radojević, D. (2005). „Nova direktiva Evropske unije o odgovornosti u oblasti zaštite životne sredine", Međunarodni problemi, Vol. 57, no. 1-2, pp. 177-198.

Slavnić, J. (2011). „Posebne odredbe o obaveznom osiguranju od odgovornosti kao predmet regulisanja zakona koji uređuje ugovor o osiguranju - Prilog raspravi o regulisanju ugovora o osiguranju u novom Građanskom zakoniku Srbije" in: Slavnić, J. and Pak, J. (editors): Promene u pravu osiguranja Srbije u okviru evropskog (EU) razvoja prava osiguranja (173-215). Belgrade: Serbian Insurance Association.

Conditions for Liability Insurance, Енергопројект Гарант АДО, 29.3.2016.

Conditions for Business Liability Insurance for Third-Party Damages, Wiener Städtische Insurance, WS.C06.1. C. 2110, 15.1.2007. 
1116

Conditions for General Liability Insurance, Бенерали Осигурање Србија, 16.10.2013.

Šarković. A, Cvejić S. Bogdanov, N. (2016). „Ekološka svest poljoprivrednih proizvođača u Srbiji: Stavovi prakse", Teme, g. XL, No. 2, pp. 729-745.

Šulejić, P. (1995). Komentar uz čl. 898300 in: Komentar Zakona o obligacionim odnosima, Book II, (editor in chief: Dr prof. Slobodan Perović). Belgrade: Contemporary Administration.

\title{
УПОРЕДНИ ОКВИР ЗА ОСИГУРАЫЕ ОД ОДГОВОРНОСТИ ЗА ЕКОЛОШКУ ШТЕТУ
}

\author{
Озрен Узелац ${ }^{1}$, Марио Лукиновић² \\ ${ }^{1}$ Универзитет у Новом Саду, Економски факултет у Суботици, Суботица, Србија \\ ${ }^{2}$ Универзитет Унион, Правни факултет, Београд, Србија
}

\section{Резиме}

Законом о заштити животне средине прописана је обавеза осигурања од одговорности за случај штете када постројење или активност представљају висок степен опасности по здравље људи и животну средину. Свако ко претрпи штету има право на накнаду штете. Захтев за накнаду штете може се поднети загађивачу или осигуравачу. Одговорност за загађење значи одговорност за штетну промену биолошких, хемијских или физичких карактеристика земљишта и воде услед испуштања штетних материја које могу довести до таквих промена. Правни однос, као извор опасности у осигурању од одговорности за животну средину, произлази, на пример, на основу радног односа лица код осигураника или коришћења ствари осигураника када осигураник не упозори лице коме је предао ствар на употребу на њене скривене мане или својства, док се у условима осигурања домаћих осигуравача, поименце, не наводе активности у вези са којима може настати еколошка штета.

Осигуравач је ослобођен од потраживања због намерних дела осигураника, а то се правило огледа у дефиницији осигураног случаја као појединачног, изненадног и неочекиваног одступања од редовног. Услови осигурања у Србији обезбеђују ретроактивно покриће две године пре закључења полисе осигурања без обзира на жеље власника полисе, што би, по мишљењу аутора овог рада, требало препустити могућности преговарања у случају потребе. 